\title{
NO SEARCH RESULTS IN FAIRNESS: ADDRESSING JURORS' INDEPENDENT RESEARCH IN THE 21ST CENTURY
}

\author{
Oscar Battell-Wallace*
}

\begin{abstract}
The right to a fair trial is one of the fundamental pillars on which the criminal justice system stands. In the digital age of the 21 st century, that pillar has increasingly come under siege due to the rise of the "Googling juror". In light of the recent proposals by the Law Commission to address this problem, this article does two things. It begins by investigating the reasons why jurors conduct independent research in the digital age, before proposing methods to prevent jurors from doing so. This article argues that jurors are researching in greater numbers than in the past due to cognitive changes to people's brains in the digital age. Those cognitive changes are the increasing use of the Internet as a transactive memory partner, people's need for instantaneous knowledge and people's reliance on the Internet for everyday needs. Given these findings, this article argues that the Law Commission's proposals are insufficient; to deal with the problem the judicial system must modernise. This article puts forward three proposals: deploying more technology in the courtroom, implementing a comprehensive system of judicial education and empowering jurors to ask more questions. It finally concludes that if the judicial system modernises, trial by jury can and should persist.
\end{abstract}

\section{INTRODUCTION}

No right is more inviolate than the right to a fair trial. Not only is it the fundamental right of the individual but it permeates the very fabric of a free and democratic society. The notion that a person should be required to face a trial and endure the punishment which a conviction would bring, when the fairness of that trial cannot be assured, is repugnant. ... the right to a fair trial is as near an absolute right as any which can be envisaged ... 1

* Submitted as part of the LLB (Hons) programme at Victoria University of Wellington. I could not be more grateful for all the insight, support and guidance I received from my supervisor, Associate Professor Yvette Tinsley. Thank you also to my family and friends for looking over my drafts.

$1 \quad R v$ Hines [1997] 3 NZLR 529 (CA) at 562 per Thomas J, restated in $R v$ Burns [2002] 1 NZLR 387 (CA) at [10]. 
At its core, the right to a fair trial requires that the jury decide the case solely on the evidence presented in court. $^{2}$

For centuries, the legal profession has grappled with how new technologies have affected juries and the right to a fair trial. In the 20th century, the rise of mass media was predicted to be the death of trial by jury. ${ }^{3}$ Yet the system endured. Now once again, in the digital age of the 21 st century, the jury system is under threat, having found itself heading full sail into unchartered waters. Never before has information been so ubiquitous, nor have people relied on technology so much to provide them with knowledge.

The digital age has brought with it the advent of the "Googling juror", namely jurors who conduct their own research on the Internet in relation to the case over which they preside. ${ }^{4}$ It is a broad term that encompasses all electronic searches including, but not limited to: definitions of legal terminology, looking up details of the accused, attempting to conduct experiments and using online mapping software to visit the crime scenes. ${ }^{5}$

The Googling juror presents unprecedented challenges for the legal profession. Not only do jurors likely conduct more research than they previously did, but the way people understand and access information has fundamentally changed. This article will begin, in Part II, by briefly introducing the problem of the Googling juror. It will do this by explaining the harms Googling jurors inflict on the judicial system and by examining how prevalent the problem is. Part III will examine the cognitive changes to people's brains in the digital age. It will specifically focus on how the digital age has changed the fundamental reasons why people search for information and the way people interact with information they obtain through research. Finally, Part IV will evaluate a range of different proposals aimed at addressing and preventing the harms caused by Googling jurors. This will include: examining the current approach; assessing the Law Commission's proposed approach, adopted in the Administration of Justice (Reform of Contempt of Court) Bill 2018; ${ }^{6}$ and putting forward proposals to prevent jurors conducting independent research.

2 Roxanne Burd and Jacqueline Horan "Protecting the right to a fair trial in the 21 st century - has trial by jury been caught in the world-wide web?" (2012) 36 Crim LJ 103 at 104 (referencing Murphy v R [1989] HCA 28, [1989] 167 CLR 94 at 98-99).

3 Dennis Sweeney, Retired Circuit Court of Appeal Judge "The Internet, Social Media and Jury Trials: Lessons Learned from the Dixon Trial" (address to the Litigation Section of the Maryland State Bar Association, Baltimore, 29 April 2010).

4 Ian Cram "Dealing with the Googling juror: A Commentary on Part 3 of the Criminal Justice and Courts Bill" (2014) 19 Comms L 110 at $110-111$.

5 David Harvey "The Googling Juror: The Fate of the Jury Trial in the Digital Paradigm" [2014] NZ L Rev 203 at 206.

6 Administration of Justice (Reform of Contempt of Court) Bill 2018 (39-1), cl 19 
This article will ultimately argue that, in order for jury trials to remain fair, it is necessary for the legal profession and jury system to modernise and begin incorporating and utilising new digital technologies. Additionally, it will conclude that, notwithstanding these changes, the judicial system can evolve to meet these challenges and trial by jury can and should persist.

\section{INDEPENDENT JUROR RESEARCH: HARMS AND PREVALENCE}

\section{A Harms Caused by Independent Juror Research}

The criminal justice system in New Zealand is predicated on the right to a fair trial. This is enshrined in the New Zealand Bill of Rights Act 1990, ${ }^{7}$ and is found in international treaties to which New Zealand is a signatory. ${ }^{8}$ As will be demonstrated, independent juror research undermines the right to a fair trial. The four harms that result from the erosion of that right will then be considered.

For a trial to be fair, a jury must decide the case solely on the evidence presented to it in court. ${ }^{9}$ Someone accused of a crime must know the evidence against him or her and have a chance to disprove it. ${ }^{10}$ This notion has existed since the inception of the jury system. In 1907, in the Supreme Court of the United States, Holmes J stated: ${ }^{11}$

The theory of our system is that the conclusions to be reached in a case will be induced only by evidence and argument in open court, and not be any outside influence, whether of private talk or public print.

Recently, the Lord Chief Justice of England and Wales "considered that the jury system depended upon contestable evidence rather than secretly acquired or inaccurate information which may be unaddressed by the parties". ${ }^{12}$ In New Zealand, the notion that a jury must decide the case solely on the evidence presented in court has been confirmed through case law and legislation. ${ }^{13}$

7 Sections 24-25.

8 International Covenant on Civil and Political Rights 999 UNTS 171 (opened for signature 16 December 1966, entered into force 23 March 1976), art 14; and Universal Declaration of Human Rights GA Res 217A, A/Res/217 (1948), art 10.

9 Mussa v R [2010] NZCA 123 at [29] and [37]; and Solicitor-General v Radio Avon Ltd [1978] 1 NZLR 225 (CA) at [233].

10 Andrew Ashworth Human Rights, Serious Crime and Criminal Procedure (Sweet \& Maxwell, London, 2002) at 32 .

11 Patterson v Colorado 205 US 454 (1907) at [462].

12 Harvey, above n 5, at 206 (referencing Lord Judge, Lord Chief Justice of England and Wales "Jury Trials" (Judicial Studies Board Lecture, Belfast, 16 November 2010)).

13 New Zealand Bill of Rights Act 1990, ss 24-25; Evidence Act 2006, s 6; Mussa v R, above n 9, at [37]; and Solicitor-General v Radio Avon Ltd, above n 9, at [233]. 
As such, when jurors undertake independent research they directly undermine an accused's right to a fair trial; the juror is removing the accused's ability to know and examine the evidence against him or her. ${ }^{14}$ The accused has no opportunity to disprove the information. Additionally, the juror may come across and be influenced by false information or prejudicial evidence that was deemed or would be deemed inadmissible. This can be harmful as "extraneous information completely evades the safeguards of the judicial process". ${ }^{15}$

The scale of the harms caused by jurors who conduct research should not be underestimated; the erosion of the right to a fair trial has wide-ranging consequences. In the context of jurors undertaking independent research, there are four primary harms.

First, there is a potential for a jury to come to the wrong conclusion. Evidential and procedural rules exist to ensure the outcome of a case is correct. ${ }^{16}$ As Ashworth remarked, "it seems axiomatic that the achievement of accurate outcomes should be the primary aim of criminal procedure and the laws of evidence". ${ }^{17}$ When jurors conduct independent research, they bypass those rules. Any inadmissible information they obtain whilst researching is likely prejudicial and could result in a false conviction. This could happen, for example, if a juror came across a defendant's prior criminal history, something that has a risk of being unfairly prejudicial. ${ }^{18}$ It must be for the judge, not the juror, to look at the probative value of a defendant's criminal history in each circumstance and weigh it against its prejudicial nature. The judge must help the jury come to the correct decision using the laws of evidence and the jury must not bypass those laws.

Additionally, in circumstances where independent research does not result in jurors finding prejudicial information, a juror may still encounter irrelevant or incorrect information that he or she believes to be relevant or correct. This could also harm the judicial process as it could influence the jury's decision-making process. For example, jurors may come across incorrect legal definitions or information about someone with the same name as the defendant. If a juror considers information of that kind relevant, the final outcome would likely be materially affected.

The second consequence of jurors conducting independent research is that it entrenches power imbalances between the state and the defendant. The laws of evidence are often cited as having a secondary purpose of helping to create an equality of arms between the state and the defendant. ${ }^{19}$ This

14 United States v Fumo 655 F 3d 288 (3rd Cir 2011) at 305.

15 United States v Resko 3 F 3d 684 (3rd Cir 1993) at [4].

16 Jeremy Bentham and John Bowring The Works of Jeremy Bentham (William Tait, Edinburgh, 1838-1843) vol 7; and Ashworth, above n 10, at 7.

17 Ashworth, above n 10, at 7

18 At 8 .

19 At 8-9. 
is because the state is all-powerful. It has access to vast quantities of information and resources and has wide-ranging powers. As such, evidential rules provide the accused with certain rights which they can rely on to protect them from the state's powers. When jurors bypass the laws of evidence by researching, they exacerbate those imbalances; they harm the defendant's ability to successfully present a defence.

Third, independent juror research can undermine public confidence in the judicial system. In the event a court manages to identify that a juror has undertaken research, the public is likely to be less trusting of the court's ability to ensure a fair trial. Similarly, where a court does not discover a juror who has researched, that juror may tell family or friends that he or she conducted independent research, which would also result in diminished confidence in the judicial system. As was stated in Attorney General v Fraill: ${ }^{20}$

\footnotetext{
If jurors make their own inquiries into aspects of the trials with which they are concerned, the jury system as we know it, so precious to the administration of criminal justice in this country, will be seriously undermined, and what is more, the public confidence on which it depends will be shaken. The jury's deliberations, and ultimately their verdict, must be based - and exclusively based - on the evidence given in court ...
}

Public confidence in the criminal justice system is essential to a functioning society. ${ }^{21}$ When public confidence in judicial institutions is undermined, people use those institutions less. ${ }^{22}$ People are less likely to report crimes when they do not believe the crimes will be resolved fairly and impartially. Instead people are more likely to employ other methods of dispute resolution. Whilst it is unlikely that Googling jurors will lead to massive distrust of the judicial system, on the margins, particularly for already disenfranchised people, the current institutions will be trusted less when the integrity of the institutions' decision-making process cannot be assured.

Finally, there are harms to the parties involved in the trial. ${ }^{23}$ Independent juror research often results in mistrials, meaning the case may need to be heard afresh. ${ }^{24}$ Being on trial for a criminal offence is emotionally taxing. The judicial system should decide cases expediently, so people found not guilty do not suffer undue hardship. Similarly, trials can be emotionally and psychologically

20 Attorney General v Fraill [2011] EWHC 1629 (Admin), [2011] 2 Cr App R 21 at [29], restated in Attorney General v Dallas [2012] EWHC 156 (Admin) at [42].

21 Richardson Oakes and A Davies "Justice must be seen to be done: a contextual reappraisal" (2016) 37 Adel LR 461 at 476; and Murray Gleeson, Chief Justice of Australia "Public Confidence in the Judiciary" (Judicial Conference of Australia, Launceston, 27 April 2002).

22 Gleeson, above n 21.

23 Law Commission Contempt in Modern New Zealand (NZLC IP36, 2014) at [5.21].

24 At [5.21]-[5.22]. 
harmful for victims and their family members. ${ }^{25}$ When mistrials happen due to independent juror research, this extends the length of time someone is on trial and results in victims being unable to get closure.

It is important to recognise that these harms are not reliant on a juror sharing information with other jurors. All it takes is for one juror to convince the others to convict a defendant, or for one juror to be found to have researched for a mistrial to be declared. Jurors sharing information may exacerbate the harm caused but is not necessary for its existence. Therefore, measures proposed to address the phenomenon must focus on preventing it and not just punishing the conduct on the rare occasion that it is identified.

\section{B How Prevalent is the Phenomenon?}

Research utilising different methodologies has shown that Googling jurors exist. However, due to the unique nature of the problem, and the fact that deliberations are confidential in most jurisdictions, the exact prevalence of the Googling juror is impossible to ascertain, and current studies likely underrepresent the number of jurors who engage in independent research.

The leading studies are based on self-reporting surveys. There have been three studies of significance that all suggest that the problem is relatively widespread. The first study was done prior to the Internet age, in 1998, in New Zealand. ${ }^{26}$ It found that in five of 48 trials jurors made "external inquiries about factual material", 27 and "apart from these ... jurors not infrequently attempted to obtain additional information". ${ }^{28}$ More recently, in the United Kingdom, Cheryl Thomas undertook two studies. ${ }^{29}$ In 2010, she found that 12 per cent of jurors in high profile cases and five per cent of jurors in standard cases admitted to researching about the case. ${ }^{30}$ Her 2013 study found that seven per cent of jurors in all cases reported having done so. ${ }^{31}$

Studies examining judges' and other professionals' opinions have also been used to ascertain the prevalence of the Googling juror. These studies have suggested the problem is not hugely

25 Ken Eikenberry "Victims of Crime/Victims of Justice" (1987) 34 Wayne L Rev 29 at 30-32.

26 Law Commission Juries in Criminal Trials: Part Two (NZLC PP37, 1999). The data collection and analysis were done by Warren Young, Neil Cameron and Yvette Tinsley.

27 At [7.42]-[7.43]

28 At [7.44]

29 Cheryl Thomas Are Juries Fair? (Ministry of Justice (UK), Research Series 1/10, February 2010); and Cheryl Thomas "Avoiding the perfect storm of juror contempt" (2013) Crim LR 483

30 Thomas Are Juries Fair?, above n 29, at 43

31 Thomas "Avoiding the perfect storm of juror contempt", above n 29, at 491. 
widespread. ${ }^{32}$ For example, the Law Commission found that 58 per cent of judges surveyed reported never having had reason to suspect jurors had used the Internet to research, 29 per cent thought it happened once or twice, and only 10 per cent thought it happened in some cases. ${ }^{33}$

However, the current studies incontrovertibly underestimate the true prevalence. Thomas admitted herself that her percentages likely reflect the minimum number of people who conduct research. ${ }^{34}$ This is because self-reporting based studies ignore the incentives acting on jurors to not admit to having committed a crime or having acted contrary to judges' instructions. Similarly, they rely on jurors knowing they have undertaken research, which as is discussed later is not always the case. ${ }^{35}$ Any studies that rely on judges' opinions can only be used as a base reference from which the prevalence can be extrapolated; they rely on jurors either being caught or a juror informing the judge that a fellow juror has conducted research, something that jurors have self-reported they are unwilling to do. ${ }^{36}$

As such, the studies suggest that there is a substantial danger to the fundamental right to a fair trial that must be addressed. Even if they do not underestimate the number of jurors who Google, there is still a significant number of cases where juries have been compromised.

\section{HOW HAS THE DIGITAL AGE AFFECTED JUROR RESEARCH BEHAVIOUR?}

That a juror may undertake research is neither a new nor novel notion. The legal profession has been grappling with how to prevent, deal with, and punish independent juror research since the establishment of trial by jury. ${ }^{37}$ However, the Googling jurors of the 21 st century have unique characteristics which separate them from jurors who conducted research previously. Aside from the unique qualities identified by the Law Commission, ${ }^{38}$ there are two fundamental changes to how people's brains work in the digital age that are crucial to understanding how the problem of the Googling juror should be addressed. The first cognitive change concerns the motivation behind digital

32 Thaddeus Hoffmeister "Google, Gadgets, and Guilt: Juror Misconduct in The Digital Age" (2011) 83 U Colo L Rev 102 at 107; and Law Commission, above n 23, at [5.30].

33 Law Commission, above n 23, at [5.30].

34 Thomas Are Juries Fair?, above n 29, at 43-44.

35 See Part III(B) of this article.

36 Law Commission of England and Wales Contempt of Court (1): Juror Misconduct and Internet Publications $(\mathrm{LC} 340,2013)$ at $[3.71]$.

37 Robbie Manhas "Responding to Independent Juror Research in the Internet Age: Positive Rules, Negative Rules, and Outside Mechanisms" (2014) 112 Mich L Rev 809 at 809-810. For early examples see Medler v State 26 Ind 171 (1866) at 172; and $R v$ Willmont (1914) 10 Cr App R 173 (CCA).

38 Law Commission, above n 23, at [2.58] and [5.5]-[5.6]. 
research by jurors, and the second looks to how jurors interact with that information once they have obtained it.

\section{A How the Digital Age has Changed Jurors' Motivations to Research}

Hoffmeister proposed that there are traditionally three kinds of jurors who research. ${ }^{39}$ The first is conscientious jurors, namely those who research because they aspire to do a good job; they genuinely believe more information will help them to reach a correct conclusion. Second, there is the confused juror, someone who believes they have failed to understand some aspects of the trial. Finally, there are curious jurors. This category contains jurors who are interested in evidence that has not been admitted or presented, and jurors who want to know more about the trial, accused or victim. These three categories are not distinct. Any individual juror could fit into multiple categories and therefore may have a combination of reasons for conducting research.

These three categories do not show the full picture in the digital age. The way in which technology has affected how people think must be examined to understand why the class of jurors who conduct research seems to have expanded. There are three significant changes to consider.

\section{The Internet as a transactive memory system}

The first major change concerns humans' reliance on the Internet as a "transactive memory system". The term "transactive memory system" was first proposed by Wegner and others in $1985 .{ }^{40}$ It originally referred to the interdependence of minds in a group or relationship setting. ${ }^{41}$ Transactive memory systems "consist of two key elements: internal memory ('What do I know?') and external memory ('Who knows what?')". ${ }^{42}$ Initially, this theory demonstrated that individuals in a group become responsible for each of their own topic knowledge areas. Instead of everyone in a group knowing everything, members of the group know: (1) what they know; (2) who knows what; and (3) whom to ask about each topic knowledge area. This increases cognitive efficiency because not every member has to remember every extraneous detail or piece of information. ${ }^{43}$

39 Hoffmeister, above n 32, at 111-113.

40 Daniel Wegner, Toni Giuliano and Paula Hertel "Cognitive interdependence in close relationships" in William Ickes (ed) Compatible and incompatible relationships (Springer-Verlag, New York, 1985) 253.

41 Daniel Wegner "Transactive memory: A contemporary analysis of the group mind" in Brian Mullen and George Goethals (eds) Theories of Group Behaviour (Springer-Verlag, New York, 1987) 185.

42 Matthew Fisher, Mariel K Goddu and Frank C Keil "Searching for Explanations: How the Internet Inflates Estimates of Internal Knowledge" (2015) 144 J Exp Psychol 674 at 674 (referencing Andrea Hollingshead "Communication, learning, and retrieval in transactive memory systems" (1998) 34 J Exp Soc 423 at 428 and 439).

43 Adrian Ward "Supernormal: How the Internet Is Changing Our Memories and Our Minds" (2013) 24 Psychol Inq 341 at $344-346$. 
Because the Internet does not seek knowledge from a person and because no negotiation for the responsibility of holding knowledge takes place, some argue the Internet does not have the fundamental features of a transactive memory system. ${ }^{44}$ However, most contemporary theoretical and empirical research suggests the Internet is used as a transactive memory partner for the following reason: ${ }^{45}$

... to access knowledge in the transactive memory system, the Internet user must navigate the Internet's information in much the same way that one transactive memory partner might know about and query the knowledge contained in another's mind. This interactive aspect of accessing knowledge on the Internet distinguishes it from the way our minds access other information sources. With its unique, supernormal characteristics that allow us to access it much the same way we access human minds, the Internet might be more similar to an ideal memory partner than a mere external storage device. In short, the cognitive systems may well be in place for users to treat the Internet as functionally equivalent to an all-knowing expert in a transactive memory system.

As such, the Internet meets the selection criteria for a memory partner as it is "entrusted with encoding, storing and producing information". ${ }^{46}$ This transactive relationship between the Internet and people has likely resulted in an increase in the number of jurors who conduct research during trials for three reasons.

First, transactive memory systems result in increased "cognitive offloading", ${ }^{47}$ the idea that people offload responsibility for knowledge to a memory partner as it takes less mental effort to remember how to find that knowledge than it takes to commit it to memory. "By reducing redundancy, transactive memory systems work to encode, store, and retrieve information more efficiently than could be done by an individual." 48 This means that when people know information will be readily available on the Internet, they see less of a need to commit that information to memory and thus will offload that information. ${ }^{49}$ As Fisher and others outlined: ${ }^{50}$

The Internet is the largest repository of human knowledge and makes vast amounts of interconnected information easily available to human minds. People quickly become accustomed to outsourcing cognitive

44 Fisher, Goddu and Keil, above n 42, at 675.

45 At 675 .

46 Ward, above n 43, at 343.

47 Betsy Sparrow, Jenny Liu and David Wegner "Google effects on memory: Cognitive consequences of having information at our fingertips" (2011) 333 Science 776.

48 Fisher, Goddu and Keil, above n 42, at 674.

49 Benjamin Storm, Sean Stone and Aaron Benjamin "Using the Internet to access information inflates future use of the Internet to access other information" (2016) 24 Memory 717 at 717.

50 Fisher, Goddu and Keil, above n 42, at 674-675 (citations omitted). 
tasks to the Internet. They remember where to find information and rely on the Internet to store the actual information.

In the context of a jury trial this is problematic as jurors know they can, in practice, access the Internet. Whilst they may know they should not use the Internet, the fact that it exists results in people subconsciously offloading knowledge that can be attained on the Internet. In a recent study, people were instructed to remember certain pieces of information for a quiz and not to rely on the Internet. However, the mere knowledge that they would not be prevented from accessing the Internet resulted in them committing less knowledge to memory. ${ }^{51}$ In trials, jurors will often perceive the Internet as more of an expert than they are, particularly in relation to matters such as legal terminology or basic facts about the case. Therefore, they will be more likely to access the Internet.

Second, the very nature of a transactive memory system is that people become reliant, through using that system, on accessing their memory partner for information. ${ }^{52}$ Recent evidence suggests that as people use the Internet more, they become more reliant on it in the future to provide them with information. ${ }^{53}$ This presents problems for jury trials because whenever people are uncertain, curious, or even conscientious, they will naturally use the Internet to find out what they need to know; the Internet is their trusted memory partner. The Internet has become many people's first port of call when they need to retrieve or be provided with information. ${ }^{54}$ Moreover, the Internet is unique because people perceive it as being an expert memory partner. ${ }^{55}$ So, much like being able to personally and privately access an expert, jurors now feel like they have an expert on hand upon whom they can rely. They therefore see less of a need to go to the judge or fellow jury members. Some jurors may still rely on the judge to provide them with information, but many will first turn to the transactive memory system they have an established relationship with and perceive to be an all-knowing expert.

In the past, there was no transactive memory system like this that existed. ${ }^{56}$ People did not have access to perfect memory partners whom they could trust completely, could readily access, and whom they had a history of accessing for information. Accordingly, few jurors felt the same need to seek out information when unsure.

These unique characteristics of the Internet mean people are only likely to become more reliant on it as they continue to use it more. If unaddressed, the problem of Googling jurors is only likely to

51 Sparrow, Liu and Wegner, above n 47, at 776-777.

52 Storm, Stone and Benjamin, above n 49.

53 At 722

54 At $721-722$

55 Adrian Ward "Why People Mistake the Internet's Knowledge for Their Own" (PhD Thesis, Harvard University, 2013) at 10-11.

56 Ward, above n 43, at 341-343. 
get worse, particularly given that people will see the courts' processes as increasingly artificial if they do not adapt and provide people with analogous memory partners.

Third, transactive memory systems result in people doubting their own knowledge if they believe their memory partner is more of an expert in the area than they are. ${ }^{57}$ As people perceive the Internet as an all-knowing expert, this means they often doubt their own knowledge on topics. Simply being able to access the Internet causes people to be less willing to rely on their own understanding of concepts even when they know the answer. ${ }^{58}$

Jurors know they can access the Internet when they leave the courtroom. Therefore, they are more likely to doubt their own knowledge and understanding of the case than prior to the Internet. Firsttime jurors are already confused due to the novel environment, duties and delivery of information they encounter in the courtroom. Knowing they can access the Internet will intensify the doubt in their minds. Accordingly, first-time jurors will be particularly likely to access the Internet. Judges can somewhat counter any doubt the Internet causes by summing up facts or definitively stating law. However, where judges have not specifically said anything or when jurors are confused or unsure, the knowledge that they can access the Internet will exacerbate their doubt and make them more likely to conduct research. Additionally, conscientious jurors will also be more likely to access the Internet; they will feel more uncertain of their understanding and want to do a good job. They will conduct Internet-based research to make sure they do the best job possible.

\section{The need for instantaneous knowledge}

The second way the digital age has changed how humans think is that it has led to the rise in people demanding answers to their questions and curiosities immediately. ${ }^{59}$ People are much less accustomed to long delays in satisfying their needs in the digital age.$^{60}$ In terms of information, people expect to be able to look things up instantaneously and find immediate answers to questions they have, finding delay stressful and uncomfortable. ${ }^{61}$ This is a problem because trials tend to be lengthy processes. Jurors ask few questions and deliberations are only at the end of the trial. ${ }^{62}$ On top of this, judicial instructions can be unclear, the relevance of evidence or legal terms may not be apparent from

57 Evan Risko and Sam Gilbert "Cognitive Offloading" (2016) 20 Trends Cogn Sci 678 at 682-683.

58 Amanda Ferguson, David Mclean and Evan Risko "Answers at your fingertips: Access to the Internet influences willingness to answer questions" (2015) 37 Conscious Cogn 91 at 98-99.

59 Ian Rowlands and others "The Google generation: the information behaviour of the researcher of the future" (2008) 60 Aslib Proc 290 at 300.

60 At $300-303$.

61 Kassandra Barnes, Raymond Marateo and Pixy Ferris "Teaching and Learning with the Net Generation" (2007) 4 Innovate: Journal of Online Education 1 at 2.

62 Hoffmeister, above n 32, at 139-141. 
the beginning, and expert witnesses may be poor at explaining complex topics. All of these factors will lead to people being confused or uncertain. It will increase the number of jurors who will conduct their own research as the Internet can provide those answers immediately. This psychological need for immediate answers is unique to the digital age and will require novel solutions that address it.

\section{Reliance for everyday needs}

The final way in which the digital age has changed how humans think is that it has made people reliant on the Internet for everyday needs such as communicating with friends, reading the news and keeping people entertained. ${ }^{63}$ For jury trials, this is harmful as it decreases the barriers to conducting research. Whereas prior to the digital age large amounts of effort were expended on conducting research, in the 21 st century all that is required is typing a few words into Google. Given jurors access the Internet daily, there is a greater temptation to Google about the case. Accordingly, there is a higher likelihood that a juror will conduct research.

\section{B How the Digital Age has Changed the Way People Interact with Information Obtained through Research}

Jurors who have conducted research jeopardise the right to a fair trial regardless of whether they impart that knowledge to their jury pool. Information accessed through the Internet jeopardises that right even more than knowledge acquired through traditional forms of research due to the way in which people engage with knowledge. There are two considerations: one concerns the perceived credibility of information and the other concerns people's capacity for assessing the real source of their knowledge.

First, when information is acquired through the Internet, a trusted transactive memory partner, the information is perceived as trustworthy and authoritative. ${ }^{64}$ People view the Internet as being an expert on all areas of knowledge. Whilst not everyone will trust every bit of information acquired, people will, in general, trust information that seems credible. ${ }^{65}$ This creates problems because people tend to overestimate their ability to research on the Internet and assess whether information is credible or not. In reality, people tend to be poor judges of credibility of online sources. ${ }^{66}$ A recent study demonstrated that even those accessing scholarly sites spend little time on them. Instead, those researching engaged in "power browsing", often not critically engaging with or understanding the material they read. ${ }^{67}$ This contrasts with traditional forms of research where people predominantly

63 Rowlands and others, above n 59, at 300.

64 Nicholas Carr The Shallows: What the Internet is Doing to Our Brains (WW Norton \& Co, New York, 2010) at 141 .

65 At 141

66 Rowlands and others, above n 59, at 300-303.

67 At 293-295, 300 and 306. 
fully read sources and engage with them. ${ }^{68}$ The same is true of people accessing non-academic sites. This can often lead to people misunderstanding information or not fully realising when the article they are reading does not apply to their situation. People become overconfident with the information they discover and also believe they have thoroughly researched a topic when they may not have.

In the context of a jury trial this makes it difficult for information obtained from researching on the Internet to be disproved by fellow jurors, lawyers or judges. Jurors who have conducted research will perceive themselves as more well informed than they are and weigh the information that they have obtained as more authoritative than it is. Additionally, during the trial when jurors attempt to make sense of the evidence presented to them in court, they construct a "story" to assess the credibility of the evidence. ${ }^{69}$ A juror who has conducted research will subconsciously use it in creating that story. The research will subconsciously manipulate the way they understand the evidence and will impact the story credibility assessment of evidence. This can have large impacts towards the end of the trial when a juror is weighing up the totality of all the individual pieces of evidence.

Secondly, transactive memory systems result in a reduced capacity to assess what knowledge people had before researching and what knowledge they obtained through researching. After searching on the Internet people tend to conflate their own knowledge with the knowledge they obtained from the Internet. ${ }^{70}$ This is due to the interactive process through which they go to obtain the information. ${ }^{71}$ People tend to believe they knew the obtained information all along.

For jury trials, this means when jurors research they will often genuinely believe they have always known the information they discover. When jurors then share that information with fellow jurors, they will not state that they discovered the information on the Internet. Instead they will present it as something they know to be true. This is a problem because fellow jurors will be less likely to report that a juror has conducted research; the fellow jurors will not know that the information was obtained on the Internet. Rather, the other jurors will believe it is knowledge that one of their fellow members has brought to the table through their life experiences. Given jurors are allowed to bring their life experience and are not expected to be clean slates, fellow jurors will be more likely to allow this information. $^{72}$

68 At 293 and 305.

69 Nancy Pennington and Reid Hastie "A Cognitive Theory of Juror Decision Making: The Story Model" (1991) 13 Cardozo L Rev 519 at 521-523.

70 Fisher, Goddu and Keil, above n 42.

71 Ward, above n 43, at 344 .

72 Newton Minow and Fred Cate "Who Is an Impartial Juror in an Age of Mass Media" (1990) 40 Am U L Rev 631 at $656-659$. 
Additionally, when someone feels like they personally know something and have always known it to be true, they will be more likely to have a "confirmation bias" towards information that agrees with that knowledge. ${ }^{73}$ This means during the trial they will subconsciously give more weight to evidence that aligns with their pre-established understanding.

The combined effect of jurors being more likely to access information and being more likely to believe the information results in a problem the legal profession has not previously encountered. It requires novel solutions that are tailored to the reasons why people undertake research in the digital age and the effects that the obtained information has on the brain.

\section{HOW TO ADDRESS THE PROBLEM OF THE GOOGLING JUROR}

\section{A Current Approach}

The current position in New Zealand is that when a juror researches on the Internet they are likely to be in contempt of court. ${ }^{74}$ While this issue has not been tried in a New Zealand court, the United Kingdom took the approach that researching online would be in contempt. ${ }^{75}$ New Zealand would likely follow suit. ${ }^{76}$ Where the trial judge has instructed the jury not to conduct research, jurors who research may be found liable under the statutory contempt provisions for disobeying a judge's direction. ${ }^{77}$

It is almost universally accepted that the current approach is unsatisfactory when it comes to dealing with jurors conducting research. This is because few jurors fully appreciate what contempt of court means. ${ }^{78}$ The jurors who do know that research is prohibited often do not understand what conduct amounts to research nor what to do if they discover a fellow juror has researched. ${ }^{79}$ In

73 Raymond Nickerson "Confirmation bias: A ubiquitous phenomenon in many guises" (1998) 2 Rev Gen Psychol 175

74 Law Commission, above n 23, at [5.13]

75 At [5.13]-[5.15].

76 Law Commission Reforming the Law of Contempt of Court: A Modern Statute (NZLC R140, 2017) at [4.16]. An example demonstrating that the conduct risks the right to a fair trial is found in $R(C A 679 / 2015) v R$ [2016] NZCA 444.

77 At [4.17]. See Senior Courts Act 2016, s 165; and District Court Act 2016, s 212.

78 Law Commission of England and Wales, above n 36, at [3.17]-[3.18].

79 Law Commission of England and Wales Contempt of Court: A Consultation Paper (LCCP 209, 2012) at [4.22]-[4.23]. 
addition, the current approach does not address the core reasons why jurors conduct research. Finally, judges lack guidance and are left to deal with these issues on a case by case basis. ${ }^{80}$

\section{B Law Commission's Proposed Approach}

In light of the substandard approach currently employed, and also as a response to an international trend of reforming the law of contempt, ${ }^{81}$ in May 2014, the Law Commission released an issues paper that looked to reform the law of contempt. ${ }^{82}$ As part of this project, the Commission examined the issue of jurors conducting independent research. ${ }^{83}$ After consultation, in May 2017, the Commission released its proposed approach paper. ${ }^{84}$ It proposed five methods to address the problem of independent jury research. ${ }^{85}$

First, the Commission supports the creation of a new statutory offence with clear and unambiguous language that criminalises independent juror research. ${ }^{86}$ The Law Commission's proposed statutory offence has been adopted in the Administration of Justice (Reform of Contempt of Court) Bill 2018 ${ }^{87}$ Second, the Commission recommends that the Ministry of Justice should provide jurors with more information outlining the risks of juror research, including the rationale for prohibiting research and the consequences of conducting it. ${ }^{88}$ Third, the Commission proposes changing the wording of the oath or affirmation taken by jurors after being empanelled to explicitly state that the juror would not undertake their own research. ${ }^{89}$ Fourth, the Commission recommends that judges should provide jurors with more comprehensive and consistent directions not to conduct independent research. ${ }^{90}$ Finally, the Commission "encourage[s] trial judges to consider whether it might be desirable to give juries comprehensive directions regarding asking questions in order to

80 Law Commission of England and Wales, above n 36, at [3.13]-[3.16].

81 See for example Law Commission of England and Wales, above n 36; and Irish Law Reform Commission Consultation Paper: Jury Service (LRC CP 61, 2010). See also the discussion of reforms taken by individual states of the United States in Law Commission of England and Wales, above n 79, at [4.36].

82 Law Commission, above n 23.

83 At [5.1]-[5.56]

84 Law Commission, above n 76

85 At [4.20]-[4.57].

86 At [4.20]-[4.26].

87 Administration of Justice (Reform of Contempt of Court) Bill 2018 (39-1), cl 19.

88 Law Commission, above n 76, at [4.27]-[4.33]

89 At [4.41]-[4.45].

90 At [4.46]-[4.52]. 
dissuade jurors from conducting their own inquiries". ${ }^{91}$ However, the Commission neither supports a change to the instructions to jurors about their ability to ask questions, nor a change to the current process to ask questions. ${ }^{92}$

\section{Recommendations}

Although the Commission's recommended approach is thorough and solves many unsatisfactory aspects of the current approach, the recommendations do not address the root cause of juror research in the digital age. This is despite the contemporary psychological evidence discussed above. ${ }^{93}$ Similarly, in the first reading of the Administration of Justice (Contempt of Court Bill) 2018, Members of Parliament across the political spectrum did not engage with the effects of the digital age on how people obtain and interact with information. ${ }^{94}$ Instead, they relied on deterrence and clarity in the law of contempt to prevent jurors from conducting research. ${ }^{95}$ Consequently, neither the recommendations nor the Bill will successfully prevent jurors from conducting independent Internetbased research.

What is provided for under the Commission's proposals and the Bill can never simulate a transactive memory partner, nor remove the underlying need, want or uncertainty that the Internet causes. They do not address the growing need for immediacy in the digital age. Moreover, there is clear empirical evidence that jurors still conduct research notwithstanding statutory offences, oaths and clear explanations. ${ }^{96}$ This even happens when jurors are fully informed of the consequences of doing so and the reasons why they cannot research. ${ }^{97}$ In one case, despite being warned multiple times, being caught researching, being warned again, and finally being threatened with imprisonment, members of that jury were still found to be researching. ${ }^{98}$

Therefore, this article puts forward three recommendations. First, there ought to be a greater deployment of technology in the judicial system. Second, there needs to be better judicial education about Googling jurors. Finally, contrary to the Law Commission, jurors need to be more empowered to ask questions. This article will conclude that without enacting these further proposals the Commission's measures will likely have minimal effect.

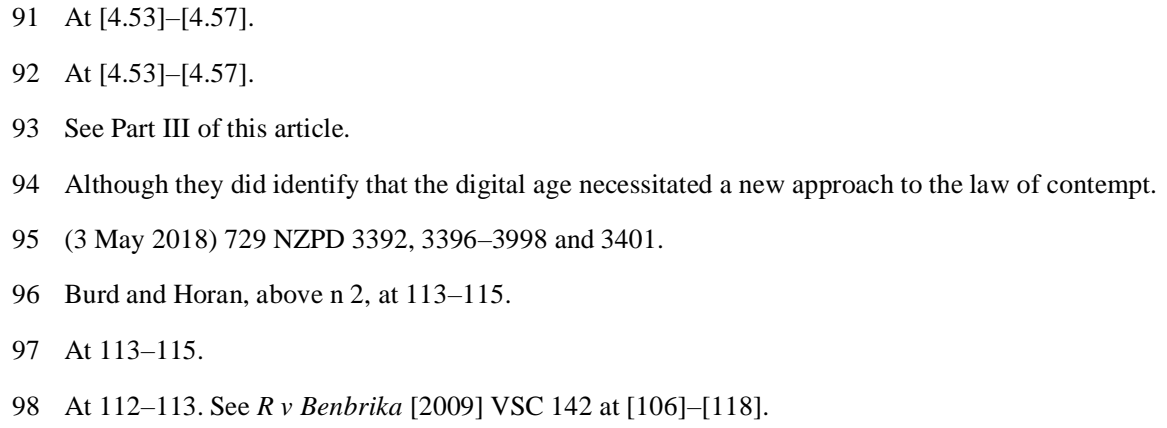




\section{Increasing technology}

Any solution to the problem of Googling jurors must address the underlying reasons why jurors conduct research. Jurors are predominantly digital natives or digital immigrants. ${ }^{99}$ As outlined in Part III, the way in which humans think has fundamentally changed. Jurors should not, of course, be allowed full and unfettered access to the Internet to look up information; rather, the judicial system should provide jurors with technology that simulates their natural transactive memory partners. Examples of this could be laptops or tablets for use during the trial and deliberations.

Jurors could take notes on these technologies during the trial. Aside from the fact that many people are more comfortable taking notes on a digital device than by hand, being able to use a device will make jurors feel more confident in their understanding of the trial. This is because jurors can use the searchable function of the device to more easily locate information they have been presented with in court. Jurors are more likely to remember details accurately, and therefore make more correct decisions, when they can refer to written notes as opposed to relying on group memory. ${ }^{100}$

Additionally, the technology could be equipped with information that is currently either given to jurors orally or in written paper form. Examples of this are: basic legal terminology, as explained by the judge; question trails; transcripts of the evidence; and copies of the indictment. ${ }^{101}$ The legal profession seems to have accepted to some extent that jurors feel more confident and make better decisions when they have written documents to refer to. ${ }^{102}$ Accordingly, it would only make sense to provide the same content through a medium that jurors find more accessible and useful.

Having both written notes and technical legal and case specific information will result in the device being treated like a transactive memory system. This is because jurors know they can rely on the device to provide them with information later. Similarly, the device is perceived as an expert on many aspects of the trial and can supply the querying juror with information on those aspects. It is the unique interactive function of being able to go on the device, search it and access expert knowledge that simulates the Internet and makes it resemble a transactive memory partner. ${ }^{103}$ Simulating a transactive memory partner will decrease the number of jurors who conduct research for four reasons.

First, it will make jurors feel more comfortable as they will be engaging with information in a way that they are used to. Digital natives are not accustomed to having to commit everything to

99 Harvey, above n 5, at 213.

100 Lynn Nadel and Walter P Sinnott-Armstrong "Memory and Jury Deliberation" in Lynn Nadel and Walter P Sinnott-Armstrong (eds) Memory and Law (Oxford University Press, Oxford, 2013) 161.

101 Harvey, above n 5, at 214-215.

102 Sarah Gray "Enhancing juror decision-making through provision of transcripts" (D Psych, Deakin University, 2004); and Harvey, above n 5, at 214-215.

103 Fisher, Goddu and Keil, above n 42, at 675. 
memory. Contemporary evidence shows that digital natives are much better at remembering where they have stored information than they are at committing large amounts of information to memory. ${ }^{104}$ Giving jurors the ability to search through information means they will no longer be required to do something their brains are not capable of doing. Instead, they will feel more confident in their understanding of the trial.

Second, the transactive memory partner will become regarded as the expert on matters relating to the case - both for evidence and legal terminology. This is essential because the device will supplant the Internet as the expert and jurors will use it as their first port of call when they are unsure. The information on the laptop will be verified and the jurors will see it as more relevant to the case at hand than the Internet. The searchable function will allow jurors to still feel empowered and like they are coming to the knowledge themselves. Having an expert memory partner will remove incentives to go to the Internet when uncertain.

Third, many jurors who search the Internet do so because it is their only option to engage with a transactive memory network, something that is necessary for many people. Jurors predominantly do not want to break the law but some feel like there is no other choice. Giving jurors a device that simulates a transactive memory system means that they are likely to choose to use that device; they do not want to be punished and can now access a memory partner.

Finally, over the course of the trial, jurors will become increasingly confident with the device and its ability to provide them with information; the more the jurors use the device, the more they will trust their memory partner. ${ }^{105}$ This trust is vital because it combats the need for immediacy of information and answers. Some jurors may conduct independent research later in the trial because they become increasingly confused and are unable to discuss the trial with anyone. This proposal directly combats that uncertainty by making them increasingly confident in their ability to find information on the device; they will feel less of a need to use the Internet.

As discussed above, there are problems with transactive memory partners, including that the information obtained on an interactive device could lead to jurors thinking they personally knew something all along or to seeing this information as more authoritative. However, this information can be regulated and checked to ensure its validity. It can be vetted by all parties and the judge. The judge's summing up notes will be even more authoritative as they will be written down and can be looked at again. Even if some problems still exist, the alternative, which is that people access the information on the Internet, is much worse.

104 Sparrow, Liu and Wegner, above n 47.

105 Storm, Stone and Benjamin, above n 49. 
A good example of a judge taking a progressive approach similar to this was outlined by Harvey. ${ }^{106}$ Harvey interviewed Wilson J who presided over a trial that took eight weeks. In that trial, the three accused were facing 29 charges. The evidence was over 1,400 pages and there were 12 Eastlight volumes of transcripts. The Judge decided to provide the material electronically so that the jury could easily search during retirement. The Judge reported that the jury was "delighted" by the fact that they could search for key documents.

On top of the benefits of having a system that simulates a transactive memory partner, other forms of technology can be introduced to help digital natives and immigrants interact with evidence in a way that reflects contemporary studies on how people learn and acquire information. ${ }^{107}$ Examples of this, as suggested by Harvey, could be: a large screen to clearly display photographic evidence; jury boxes equipped with screens so that jurors can watch recorded interviews; a greater use of Google Maps or Google Earth; and a greater use of PowerPoint to illustrate complex concepts. ${ }^{108}$ All of these different technologies reduce uncertainty. They present knowledge in a way that jurors are used to. As Morrison states: 109

[Currently] we deny jurors many of the tools we ourselves use in daily life. The jurors who take their roles seriously - and we can assume that they are in the majority - face a lonely and difficult task, which can cause them great anxiety.

These technologies make information learning a more active experience. The learning process is not passive and the legal profession should not try and force it to be. ${ }^{110}$ They also combine multiple learning methods to assist jurors to understand information. They combine oral, visual and kinaesthetic learning as opposed to heavily relying on oral evidence. Technology as simple as PowerPoints on projectors results in an increased understanding of complex topics. ${ }^{11}$ These technologies will decrease uncertainty and result in jurors being less likely to use the Internet.

\section{Judicial education}

Little has been written regarding judicial education on independent Internet-based research. The author could find no evidence of a comprehensive system to educate judges in New Zealand about the

106 Harvey, above n 5, at 222-223.

107 John Bransford, Ann L Brown and Rodney Cocking How People Learn: Brain, Mind, Experience, and School (National Academic Press, Washington (DC), 2000) at 10, 12-13 and 124-125.

108 Harvey, above n 5, at 221-223.

109 Caren Morrison "Jury 2.0" (2011) 62 Hastings LJ 1579 at 1630-1631.

110 Bransford, Brown and Cocking, above n 107, at 10, 12-13 and 124-125.

111 Harvey, above n 5, at 222 (see footnote 73 - where the example used was Uniloc USA, Inc v Microsoft Corp 447 F Supp 2d 177 (RI 2006)) 
dangers of Internet-based research and the reasons why jurors conduct that research. ${ }^{112}$ Yet judges need to be educated on this. This article neither has the scope to outline the educational content nor does it have the ability to definitively state when and how judges should react to every situation of research. Instead, it will outline the reason why education is necessary. Following this, it will be for Parliament, the Institute of Judicial Studies and the judiciary to decide what the best approach is.

First, judges need education because it is unclear to what extent New Zealand judges are sceptics of the prevalence and harms of Internet-based independent juror research. Where it is unclear, the judicial system should err on the side of caution to best equip the judges with the tools necessary to do their job. The survey done by the Law Commission suggests that judges are sceptics as almost no judges believed that many jurors undertook research. ${ }^{113}$ Similarly, New Zealand judges seem to be loath to impose penalties on jurors who conduct research. ${ }^{114}$ However, there is also evidence that judges do believe that there is a problem and it is widespread. ${ }^{115}$ Regardless of how sceptical they are, few judges likely understand the unique nature of Internet-based research and the harms associated with transactive memory partners.

In drawing comparisons with other jurisdictions such as the United States, judges in New Zealand seem more progressive, educated and understanding when it comes to independent juror research. In the United States, there is ample evidence that judges do not take the issue seriously. An example of this is in Magee $v$ Williams, ${ }^{116}$ where the Judge simply dismissed research as not affecting the integrity of the jury's decision because only one juror had done research and the verdict did not need to be unanimous. ${ }^{117}$ Another example is where an appellate Judge essentially mocked the issue when presenting at a conference instead of properly engaging with the subject. ${ }^{118}$ These cases and this kind of behaviour demonstrate a lack of understanding by American judges as to how jurors interact with information and how information can be disseminated unknowingly.

Whilst New Zealand judges may have more understanding of the issue than judges in other jurisdictions, education is necessary to ensure that judges cooperate with any proposals or reforms aimed at dealing with Googling jurors. For instance, when judges are more educated on how jurors

112 There is evidence of some education taking place such as presentations given by Yvette Tinsley (Assoc Prof, Victoria University of Wellington).

113 Law Commission, above n 23, at [5.30]-[5.32].

114 At [5.31]. Note also that no juror has been prosecuted in New Zealand for conducting research even though some have been caught doing so.

$115 R v B(C A 459 / 06)$ [2008] NZCA 130, [2009] 1 NZLR 293 at [78] per William Young P and Robertson J and at [50] per Baragwanath $\mathrm{J}$.

116 Magee v Williams 17 So 3d 687 (Ala Civ App 2009).

117 Harvey, above n 5, at 230.

118 Sweeney, above $\mathrm{n} 3$, at 4 and 6-7. 
process and receive information, they can make a more informed decision as to what kind of approach they want to adopt regarding mistrials and dismissals of jurors. New Zealand judges may wish to adopt any one of the three approaches currently employed in the United States to determine when a mistrial is necessary as a result of juror research. ${ }^{119}$ Alternatively, New Zealand may want to create its own approach. However, without judicial education, judges in New Zealand may not understand that it will be difficult to identify exactly what information was obtained through the Internet and what was imparted to the jury pool due to the fact that people misattribute the source of knowledge obtained through the Internet. This could ultimately result in New Zealand judges taking a harsher or more lenient approach towards mistrials than they otherwise would have had they received education.

Similarly, judges need to be educated on the necessity of incorporating technology in the courtroom and the necessity of allowing jurors to ask questions, something that, as will be discussed further, is necessary to prevent independent juror research. If judges are reluctant to incorporate new technologies or to allow jurors to ask questions, they will slow down the correct implementation of technological solutions, or they may not answer jurors' questions in a comprehensive way.

Judicial education must be implemented to ensure that judges are aware of juror research, its causes and its harms. This will empower judges to make informed decisions and will make them more cooperative with proposals.

\section{Encouraging jurors to ask questions}

The Commission also acknowledged that "the current process [for jurors to ask questions] is formal: jurors must write questions down and pass them to the court attendant who will then pass them on to the trial judge", ${ }^{120}$ yet was unwilling to change that process. Given the motivations behind juror research, jurors should be encouraged to ask more questions. They should be provided with a less "formal" way of asking questions, for example, jurors could have access to an electronic form where they can ask the judge questions.

Encouraging jurors to ask questions will inevitably decrease the number of jurors who research. It is unanimously agreed that many jurors conduct research because they are uncertain or feel confused during the case. ${ }^{121}$ Jurors often self-report wanting more information in cases. ${ }^{122}$ In the digital age, this problem is compounded by transactive memory systems and the need for instantaneous knowledge. Moreover, contemporary research demonstrates that people are active learners and need

119 Matthew Fredrickson "Conformity in Confusion: Applying A Common Analysis to Wikipedia-Based Jury Misconduct" (2013) 9 Wash J L Tech \& Arts 19 at 24-26.

120 Law Commission, above n 76, at [4.53].

121 Morrison, above n 109; Minow and Cate, above n 72; and Hoffmeister, above n 32.

122 Jacqueline Horan Juries in the 21 st Century (The Federation Press, Sydney, 2012) at 74-75. 
to be able to engage during the learning process. ${ }^{123}$ The approach of treating jurors as passive learners is archaic and ineffective. By forcing jurors to passively sit and listen, the system essentially encourages them to research. It is unacceptable to expect jurors not to ask questions, or to only ask a small number of questions, and then punish them when they turn to a medium to find out answers for fear that if they do not they may convict someone of a crime unjustly.

The two potential concerns with question-asking are: that it may detract from the case, making the trial lengthier; ${ }^{124}$ and that jurors may be more curious when a judge cannot answer a question because of evidential rules. ${ }^{125}$ However, it is an acceptable trade-off for a trial to take slightly longer if the jury is more likely to come to the correct answer and not prejudice someone's right to a fair trial. Vis-à-vis an increase in curiosity, allowing more questions has the opposite effect. ${ }^{126}$ The judge can use those questions as a catalyst to re-explain why certain questions cannot be answered. ${ }^{127}$ This only serves to make jurors less curious and less likely to research at home. Additionally, jurors asking questions signals to counsel which parts of the case are confusing. By doing this, juries help to ensure that people have fair trials as evidence will be re-explained in a more understandable manner. ${ }^{128}$

Technology could be incorporated in this process to decrease its formality. An example of this could be having an electronic forum through which jurors can submit questions to the judge. Both the prosecution and defence could have access to this form and the normal rules of admissibility would apply. In general people feel more comfortable when they can ask questions through digital forms as opposed to having to ask the question in front of others or out loud. This kind of system will work to encourage people to ask questions.

\section{CONCLUSION}

The digital age has made the world a better place. It has allowed us to communicate instantaneously and find out the answer to any question we have. However, it has brought with it new and unique challenges to the judicial system.

This article has illustrated the changes to the ways that jurors access and retain information. Unlike ever before, people now have a perfect memory partner on which they can almost always rely. That partner acts like a drug in that the more that it is used, the more that people need to use it in the future. Furthermore, the memory partner is unique in its interactive qualities. It leads to people misattributing

123 Bransford, Brown, and Cocking, above n 107, at 10, 12-13 and 124-125.

124 Law Commission, above n 76, at [4.55].

125 Hoffmeister raised this as a potential concern before rebutting it: Hoffmeister, above n 32, at 138

126 At $138-142$.

127 At $138-139$.

128 At 139 . 
sources of knowledge. The changes to how people think have meant that jurors: access the Internet more; disregard evidence presented in court; doubt their own beliefs until verified; and believe they already knew information obtained on the Internet. It has likely resulted in a massive increase in the number of jurors conducting independent research, which has jeopardised the right to a fair trial.

The Law Commission proposed a range of responses to address independent juror research. Parliament has incorporated one of these in the Administration of Justice (Reform of Contempt of Court) Bill 2018. ${ }^{129}$ The Commission's proposals work to minimise the harm caused, but ultimately do not deal with the underlying reasons why people research in the digital age. If the criminal justice system wants to retain trial by jury it must modernise to meet the challenges. It needs to look at how it can implement its own technologies and simulate transactive memory partners. The judiciary also needs to be educated about why jurors conduct research in the digital age. Judges need to encourage jurors to ask questions; it is better for a trial to run longer than a juror to feel uncertain and conduct research.

This article has suggested some technologies that could be used to prevent juror research but welcomes other suggestions on how new technology can be best incorporated. Additionally, it has left open questions about what the educational content for judges should be and when mistrials should be declared.

Regardless of all the potential problems the digital age has brought with it, juries remain an essential part of society. The jury still does and always will provide a "safeguard against the arbitrary or oppressive enforcement of the law by the government". ${ }^{130}$ It stands "between the accused and the state in a way that judges, who are sworn to apply the law, are not always able to do". ${ }^{131}$ This unique position of juries necessitates that the criminal justice system works hard to ensure they can still exist whilst also protecting the right to a fair trial. Ultimately, the criminal justice system must modernise; it must help those who give up their time to act as the conscience of society.

129 Administration of Justice (Reform of Contempt of Court) Bill 2018 (39-1), cl 19.

130 Siemer v Solicitor-General [2010] NZSC 54, [2010] 3 NZLR 767 at [20] per Elias CJ and McGrath J.

131 At [20] per Elias CJ and McGrath J. 
